\title{
Safety transport of radioactive waste in the nuclear power area
}

\author{
Ivana Tureková ${ }^{1, *}$, and Linda Makovická Osvaldová ${ }^{2}$ \\ ${ }^{1}$ UKF Nitra, Faculty of Education, Tr. A. Hlinku 1, 94974 Nitra, Slovakia \\ ${ }^{2}$ University of Žilina, Faculty of Security Engineering, Univerzitná 8215/1, 01026 Žilina, Slovakia
}

\begin{abstract}
Radioactive wastes require strict rules for manipulation with them due to the hazards for the human health and environment, not excluding the hazards during their internal transport. The article deals with the transport of packing unit inside of the company and it proposes the possible alternatives so that meet the limit conditions and reduce the manipulation time with the radioactive material in the packing unit. The packing unite isolates fixated liquid waste from the environment while it also serves as protection. There are also important external radiation characteristics of package unit, which consist of measurable values of the scratch contamination surface and dose power on the surface of package unit. Thus, the paper is aimed to point out the necessity of the logistics during manipulation with the package unit in the process of internal transport so that the dose power of exposed employees would achieve the lowest possible level and meet the strict limits in a full extent.
\end{abstract}

\section{Introduction}

Radioactive waste (RAW) treatment includes technological processes, procedures and operations used to achieve chemical and physical form appropriate for transport, storing or long-term storing of RAW [1]. In case of liquid RAW or dispersible waste, RAW treatment also includes immobilisation (solidification) [2]. Aim of RAW treatment is to create a system consisting of fixed RAW, a fixation matrix and storage/transport file (container, barrel) meeting the following requirements [3]:

- low permeability and low leachability of wastes;

- maximum load efficiency of the system (low proportion of empty space in the container);

- chemical, mechanical, thermal and radiation stability during the time required;

- limited amount of gaseous substances ;

- resistance against chemical substances and biological organisms [4].

RAW inspection before transport confirms weather the packaging file is in compliance with radiological criteria, mechanical or chemical properties applicable to the given type of the RAW waste dump. RAW transport must be carried out in accordance with the conditions stipulated by the legislation on safe RAW transport $[5,6]$ :

\footnotetext{
*Corresponding author: iturekova@ukf.sk
} 
- Observing the threshold limit values for transportation workers;

- Reducing the risks for transportation workers and people, in case of accidents, to an acceptable level by reducing radioactivity level of the load;

- Limiting unfixed RAW transport;

- Eliminating danger to persons or the environment even in case of major traffic accidents [7] .

The goal of this article is to find the safest way of manipulation RAW during transport.

\section{Fixation process of radioactive waste}

Transport in question is represented by contaminated radioactive inorganic sorbent (waste) which was created during the technological process of dowtherm cleaning. Radioactive dowtherm was used as cooling for fuel elements as a substitute for "Chrompik".

Chrompik is aqueous solution of $\mathrm{K}_{2} \mathrm{Cr}_{2} \mathrm{O}_{7}$ in a concentration of 3-5\%. Chrompik (later Dowtherm) should prevent corrosion of fuel cladding [8].

Beta and gamma activity of organic dowtherm ranges from $10^{6}-10^{9} \mathrm{~Bq} \cdot \mathrm{dm}^{-3}$ and alpha activity is at $10^{4} \mathrm{~Bq} \cdot \mathrm{dm}^{-3}$. Basic physical characteristics of the substance are specified in Table 1.

Table 1. Basic characteristics of dowtherm [9].

\begin{tabular}{|c|c|}
\hline composition & $\begin{array}{c}\text { biphenyl }(25.5 \% \text { of the volume }) / \\
\text { / diphenyl }(73.5 \% \text { of the volume })\end{array}$ \\
\hline colour & colourless to light yellow \\
\hline solidification point & $12.0^{\circ} \mathrm{C}$ \\
\hline boiling point (1 atm.) & $257.1^{\circ} \mathrm{C}$ \\
\hline flashpoint & $113^{\circ} \mathrm{C}$ \\
\hline ignition point & $118^{\circ} \mathrm{C}$ \\
\hline auto-ignition point & $599{ }^{\circ} \mathrm{C}$ \\
\hline density & $1056 \mathrm{~kg}^{-3} \mathrm{~m}^{-3}$ \\
\hline critical temperature & $497{ }^{\circ} \mathrm{C}$ \\
\hline critical pressure & $31.34 \times 10^{5} \mathrm{~Pa}$ \\
\hline critical volume & $3.17 \mathrm{dm}^{3} \cdot \mathrm{kg}^{-1}$ \\
\hline average molecular weight & $166 \mathrm{~g} \cdot \mathrm{m}^{-1}$ \\
\hline
\end{tabular}

RAW fixation is performed into organic or inorganic matrix (e.g. cement, aluminosilicate SIAL matrix).

Shielded cart with a 601 metal barrel is placed under a fixing apparatus where active inorganic sorbent has been measured out. The amount of sorbent ensures dose rate of maximum $30 \mathrm{mSv} / \mathrm{h}$ on the surface of the barrel before fixation. Dose rate on the surface of the barrel with active sorbent has been measured in the shielded truck using gamma probe, displaying the data on the control panel. Homogenisation of the inorganic sorbent is carried out using dispersion stirrer. Homogenisation is followed by fixation into inorganic SIAL matrix. The main SIAL matrix components are natural inorganic materials containing $\mathrm{SiO}_{2}$, $\mathrm{Al}_{2} \mathrm{O}_{3}, \mathrm{CaO}, \mathrm{MgO}, \mathrm{Na}_{2} \mathrm{O}, \mathrm{K}_{2} \mathrm{O}, \mathrm{Fe}_{2} \mathrm{O}_{3}$ and $\mathrm{TiO}_{2}$. Stabilization of radioactive sludge and sorbents into SIAL matrix is a cold process as the processing itself takes place at ambient temperature and the final product does not emit heat which would release gases or aerosols. Stabilisation of the product takes 28 days until the fixation matrix together with the sorbent have not reached the desired properties (leachability, compressive strength) which are the conditions for further radioactive waste treatment [10]. 
Excellent mechanical properties of the final product - high resistance against liquids, excellent radioactive stability and low leachability are the advantages of fixation into alumina-silica matrix.

The majority of mobile equipment in the nuclear power plant (NPP) uses a packaging file for LRAW (liquid radioactive waste) fixation - 2001 barrel used for transport. Packaging file consists of several layers:

1. First layer is represented by a $60 \mathrm{l}$ re-closable barrel with adjusted inner wall to increase its resistance to corrosive effects of modified and stabilized waste together with solidification matrix. Dose rate on the surface of the barrel during transport has a maximum level of $20 \mathrm{mSv} / \mathrm{h}$.

2. Another layer is represented by an adjusted 2001 barrel with a concrete lining serving as shielding. Steel pipes of different thickness may be inserted into the system to increase shielding effect. Barrels are custom made depending on the given type of radioactive waste with the corresponding dimensions of the bore, thickness of the lid and precalculated coefficient of radiation shielding [10, 11, 12].

RAW transport must be carried out in accordance with the legislation on RAW transport which includes:

- Observing the threshold limit values of effective dose for workers of transport;

- Reducing the risks for drivers and population, in case of accidents, to an acceptable level by reducing radioactivity level of the load;

- Limiting unfixed RAW transport;

- Eliminating danger to persons or the environment in case of major traffic accidents [13, $14,15]$.

Radioactive transport is controlled by a R - command. R - command is a written statement on compulsory technical and organizational measures ensuring the safety of employees at work in conditions of increased radiation risk determining the place, time and conditions for carrying out work, necessary measures and means in order to ensure radiation safety, composition of workers and persons responsible.

Limit values and restrictions during transport are stated in Table 2.

Table 2. Limit values and restrictions during transport [16].

\begin{tabular}{|c|c|c|}
\hline \multicolumn{2}{|c|}{ Restriction } & Limit value \\
\hline \multicolumn{2}{|c|}{$\begin{array}{l}\text { Radiation dose limit at R-command - } \\
\text { absorbed IED* by worker }\end{array}$} & $1 \mathrm{mSv}$ \\
\hline \multicolumn{2}{|c|}{ Maximum dose limit of a 601 barrel } & $20 \mathrm{mSv} \cdot \mathrm{h}^{-1}$ \\
\hline \multirow{3}{*}{$\begin{array}{l}\text { Dose Rate (DR) } \\
\text { for radioactive } \\
\text { material } \\
\text { transportation } \\
\text { (public notice UJD } \\
57 / 2006 \text { Coll.) }\end{array}$} & $\begin{array}{l}\text { On the surface of the } \\
\text { vehicle }\end{array}$ & $2 \mathrm{mSv} \cdot \mathrm{h}^{-1}$ \\
\hline & $\begin{array}{l}\text { On the surface of the } \\
\text { vehicle under } \\
\text { exclusive use }\end{array}$ & $10 \mathrm{mSv} \cdot \mathrm{h}^{-1}$ \\
\hline & At $2 \mathrm{~m}$ distance & $0.1 \mathrm{mSv}^{0} \mathrm{~h}^{-1}$ \\
\hline
\end{tabular}

*IED - individual effective dose

Methodology of analysis (Figure 1) shows input and restrictive parameters during LRAW transport. The goal was to optimize transportation procedure of the packaging file observing the threshold limit values total absorbed dose and reduction of transportation time of the packaging file have been established as crucial parameters. 


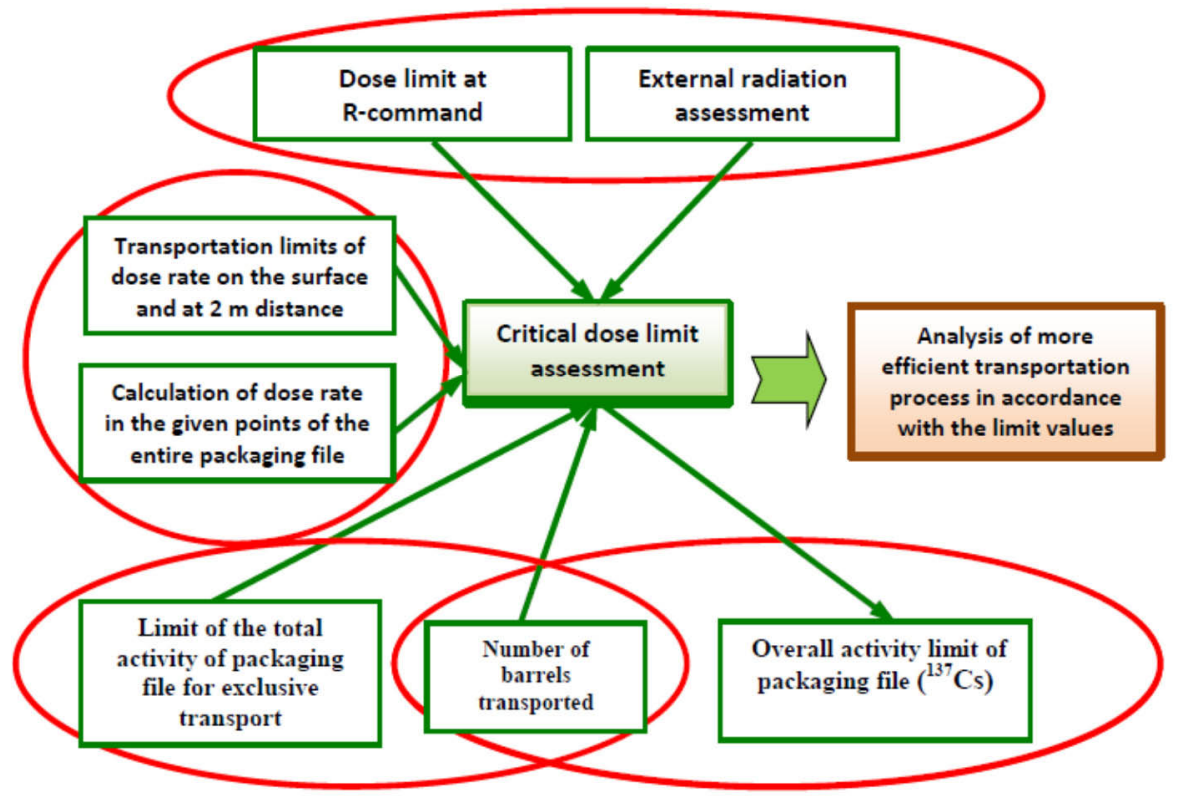

Fig. 1. Factors influencing risk analysis of packaging file transportation [17].

\subsection{Present-day situation during packaging file transportation}

Transport model (alternative 0 ) was carried out by a special transportation method with the maximum dose rate DR of $5 \mathrm{mSv} / \mathrm{h}$ on the surface of the packaging file. The dose absorbed by the workers participating in the transport is represented by the product of DR at the corresponding distance at which the worker is located during the operation and the time (t) required for the operation. Doses absorbed by the workers refer to the four shielded containers representing a packaging file with fixation product of used sorbents (4 x 601 ).

Before transportation, it is necessary to carry out operations and handling procedures which are directly related to transportation and the measurement of radioactive properties of the transported material. The initial condition is represented by a 601 barrel placed onto a shielded transport cart under the crane on the floor level of $+6 \mathrm{~m}$ (room A). The process, carried out by workers, was divided into 10 major steps (Figure 2).

Table 3 shows measurement output of dose rates and radiation load during transport. Trial measurement (alternative 0) was carried out with four pieces of 601 barrels with dose rate on the surface of the transported barrels ranging between $18.3 \mathrm{mSv} / \mathrm{h}$ and $19.7 \mathrm{mSv} / \mathrm{h}$. Increase in overall absorbed dose depending on time are shown in Figure 3. 


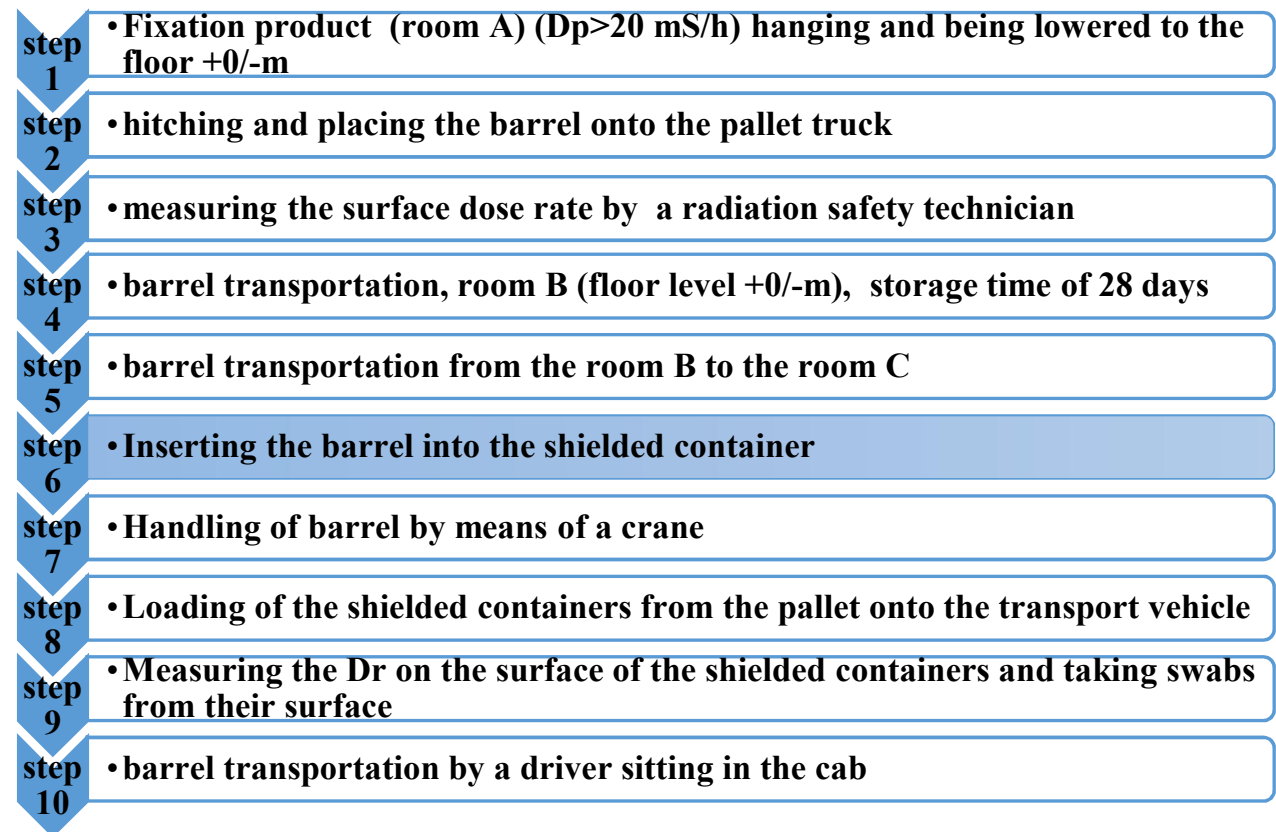

Fig. 2. Description of procedures during liquid radioactive waste transport (alternative 0).

Table 3. Calculation of radiation load during handling and transport [5].

\begin{tabular}{|c|c|c|c|c|c|c|}
\hline Step & $\begin{array}{l}\text { Number of } \\
\text { employees }\end{array}$ & $\begin{array}{c}\text { Distance from } \\
\text { the source } \\
{[\mathrm{m}]} \\
\end{array}$ & $\begin{array}{l}\text { Time } \\
{[\mathrm{min}]}\end{array}$ & $\begin{array}{c}\text { DR } \\
{[\mathrm{mSv} / \mathrm{h}]}\end{array}$ & $\begin{array}{l}\text { Dose } \\
\text { [mSv] }\end{array}$ & $\begin{array}{c}\text { Overall } \\
\text { dose } \\
{[\mathrm{mSv} / \mathrm{h}]}\end{array}$ \\
\hline 1. & 2 & $0.5-1.5$ & 8 & 0,502 & 0.066 & 0.122 \\
\hline 2. & 2 & 1.0 & 6 & 1.433 & 0.143 & 0.286 \\
\hline 3. & 1 & 2.0 & 4 & 0.232 & 0.015 & 0.015 \\
\hline 4. & 2 & 1.5 & 7 & 0.502 & 0.058 & 0.116 \\
\hline 5. & 2 & 1.0 & 5 & 1.433 & 0.119 & 0.238 \\
\hline 6. & 2 & 0.5 & 2 & 4.57 & 0.152 & 0.304 \\
\hline 7. & 1 & 2.0 & 10 & 0.232 & 0.038 & 0.038 \\
\hline 8. & 4 & 0.5 & 5 & 0.358 & 0.029 & 0.116 \\
\hline 9. & 1 & 0.5 & 6 & 0.358 & 0.035 & 0.035 \\
\hline 10. & 1 & $\begin{array}{c}2.5 \mathrm{M}+\text { shielding } \\
\text { of the cab }\end{array}$ & 40 & 0.012 & 0.008 & 0.008 \\
\hline Sum total & 17 & & 93 & & 0.663 & 1.278 \\
\hline
\end{tabular}

Step-by-step logistics of the transport recorded different increments of absorbed dose which was related to time interval of transport, dose rate of the environment, time of the procedure and distance. Insertion of the $60 \mathrm{l}$ barrels into the shielded containers seemed to be the most critical operation. The procedure, which takes 2 minutes only, is carried out by 2 employees.

From the point of view of time schedule, works were being carried out for 28 days which resulted from the technological requirements within the work program and the two different R-commands. Doses absorbed by workers transporting the fixation product of used sorbents (steps 1-4) have been carried out at one R-command and workers when transporting or packaging four shielded barrels for transmission range (steps 5-10) and the other tasks at the second R-command. All absorbed doses have been recorded into the central information system. 


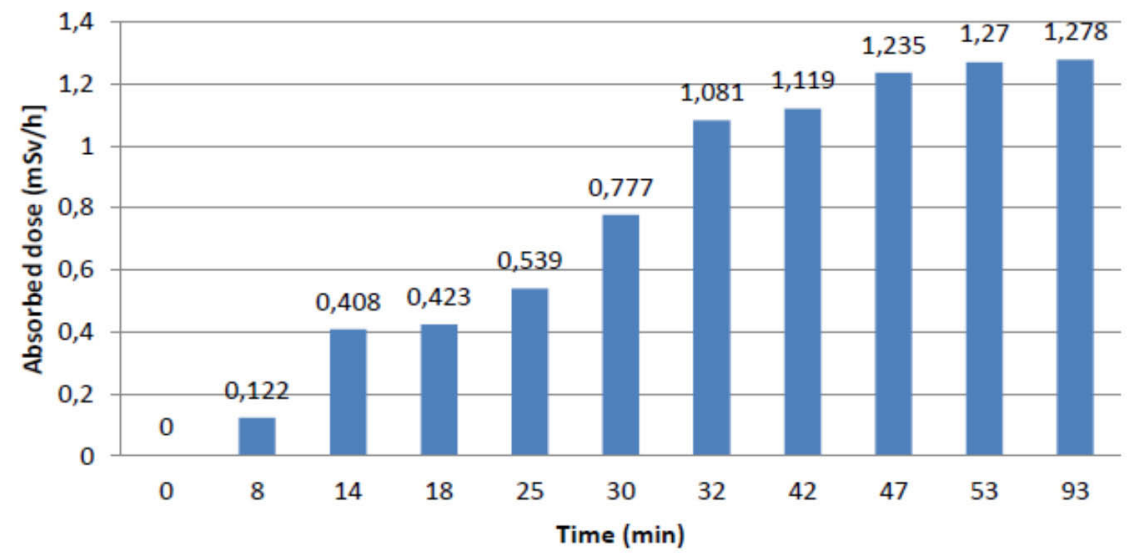

Fig. 3. Increment of overall absorbed dose for each step of the procedure depending on time (Alternative $0)$.

\subsection{New solution for handling fixation products}

Two 601 barrels of high dose rate (maximum dose rate is $20 \mathrm{mSv} / \mathrm{h}$ ) have been selected as test specimens for the experiment. Measurements have been carried out three times (see Table 4). Average values for calculating dose rate reduction coefficients depending on ionising radiation source (Table 5) according to the equation 1 were used. Dose rate reduction coefficient is defined as a ratio of maximum point dose rate measured directly on the ionising radiation source to dose rate in the given distance. In case of exclusive transport, all measurements, however, must meet one condition - dose rate at any place within the external surface of the transported unit shall not exceed $10 \mathrm{mGy} / \mathrm{h}$.

New solution for handling of fixation products

$$
\operatorname{Dp}(\mathrm{i})=\frac{\mathrm{Dp}(\mathrm{k})}{\mathrm{k}(\mathrm{i})}
$$

where:

$\mathrm{Dp}(\mathrm{i})$ - is the dose rate value measured at a distance $\mathrm{i}$ (metres) from the barrel, $\mathrm{Dp}(\mathrm{k})$ - is the dose rate value measured directly on the surface,

$\mathrm{k}(\mathrm{i})$ - is the dose rate reduction coefficient for the distance $\mathrm{i}$.

Table 4. Dose rates results of 601 barrels at different distances [5].

\begin{tabular}{|c|c|c|c|c|c|c|}
\hline \multirow{2}{*}{$\begin{array}{c}\text { Barrel } \\
\text { no. }\end{array}$} & \multirow[t]{2}{*}{ Measurement } & \multicolumn{5}{|c|}{ Dose Rate (DR) at a distance of [m] } \\
\hline & & $\begin{array}{l}\text { 0 (on the } \\
\text { surface) } \\
{[\mathrm{mSv} / \mathrm{h}]}\end{array}$ & $\begin{array}{c}0.5 \\
{[\mathrm{mSv} / \mathrm{h}]}\end{array}$ & $\begin{array}{c}1.0 \\
{[\mathrm{mSv} / \mathrm{h}]}\end{array}$ & $\begin{array}{c}1.5 \\
{[\mathrm{mSv} / \mathrm{h}]}\end{array}$ & $\begin{array}{c}2.0 \\
{[\mathrm{mSv} / \mathrm{h}]}\end{array}$ \\
\hline \multirow[t]{3}{*}{1} & 1 & 19.7 & 4.58 & 1.52 & 0.44 & 0.21 \\
\hline & 2 & 19.7 & 4.47 & 1.47 & 0.50 & 0.22 \\
\hline & 3 & 19.7 & 4.02 & 1.51 & 0.47 & 0.21 \\
\hline \multirow[t]{3}{*}{2} & 1 & 18.3 & 4.25 & 1.41 & 0.41 & 0.19 \\
\hline & 2 & 18.3 & 4.15 & 1.36 & 0.47 & 0.21 \\
\hline & 3 & 18.3 & 3.73 & 1.407 & 0.44 & 0.20 \\
\hline
\end{tabular}


Table 5. Dose rate reduction coefficients in the axis of ionising radiation source

\begin{tabular}{|c|c|c|c|c|c|c|c|}
\hline \multirow{2}{*}{$\begin{array}{c}\text { Barrel No./ } \\
\text { measurement }\end{array}$} & \multicolumn{7}{|c|}{ "c value in "i" distance [m] } \\
\cline { 2 - 8 } & 0 & 0.5 & 1.0 & 1.5 & 2.0 & 2.5 & 3.0 \\
\hline $1 / 1$ & 1 & 4.3 & 12.9 & 43.9 & 92.2 & 148.2 & 197.6 \\
\hline $1 / 2$ & 1 & 4.4 & 13.4 & 38.7 & 85.7 & 144.7 & 189.7 \\
\hline $1 / 3$ & 1 & 4.9 & 13 & 41.3 & 91 & 145.6 & 191.6 \\
\hline $2 / 1$ & 1 & 4.6 & 14.7 & 46 & 86.1 & 152.3 & 190.4 \\
\hline $2 / 2$ & 1 & 4 & 16.7 & 38.5 & 83.3 & 142.9 & 185.2 \\
\hline $2 / 3$ & 1 & 4 & 13 & 30.4 & 78.3 & 137 & 182.7 \\
\hline Average & $\mathbf{1}$ & $\mathbf{4 . 3 7}$ & $\mathbf{1 3 . 9 5}$ & $\mathbf{3 9 . 8}$ & $\mathbf{8 6 . 1}$ & $\mathbf{1 4 5 . 1}$ & $\mathbf{1 8 9 . 5}$ \\
\hline
\end{tabular}

By means of evaluation of the data obtained during the whole process of handling of the final product, the measurements - carried out under dosimetric supervision - show a considerably high radiation load for workers in one cycle of the process. One cycle includes handling and transport of four pieces of 601 barrels, whereas 83 pieces were initially considered. The new proposals' aim was to use spatial and technical equipment during RAW handling and transportation. Compliance with radiation load conditions for workers during each step as well as time reduction of such operations were the two conditions that had to be met.

Technical solutions and workplace layout enabled two alternative ways of handling of the final fixation product of used sorbents. The final fixation product of used sorbents is located in the shielded cart in room $\mathrm{A}$, at the elevation of $+6 \mathrm{~m}$. This room is linked with room $\mathrm{C}$ (elevation of $+0 /-\mathrm{m}$ ) which serves, at the same time, as a transport corridor. Both of them are linked by a crane.

\section{Results}

\subsection{Alternative 1}

Transport vehicle is prepared in room $\mathrm{C}$ below the crane from the room A. Surface of the transport vehicle is covered with polyethylene foil. A pallet for four 601 barrels is placed on the loading area at $1 \mathrm{~m}$ distance from the end of the loading area and 2 metres from the driver's cab. Two employees fix the transported barrel by a vacuum holder (Figure 4), lower it on the pallet placed on the loading area and loosen the vacuum holder. Radiation safety officer measures the DR on the transported barrel surface. This procedure is repeated three times and, in the end, after releasing the vacuum holder, workers cover the pallet with four 601 barrels with a polyethylene foil. Radiation safety officer takes a swab from the packaging file surface and evaluates the measured values of DR and surface contamination taking into account the conditions and limits for transport in nuclear power plant site.

Time schedule of each step - alternative 1 (Figure 5). 


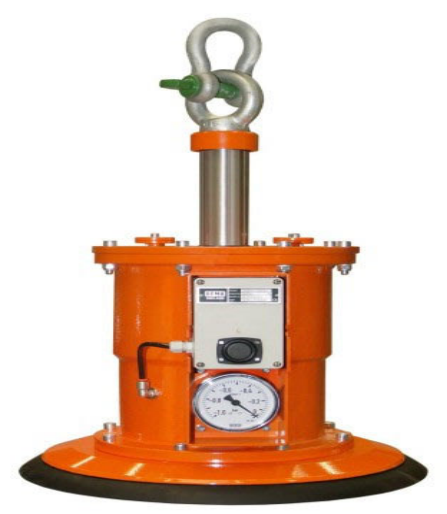

Fig. 4. Vacuum holder [5].

\begin{tabular}{|c|c|}
\hline step & $\begin{array}{l}\text { - Fixation product }(\mathrm{room} A)(\mathrm{Dp}>20 \mathrm{mS} / \mathrm{h}) \text { hanging and being lowered to the } \\
\text { floor }+0 /-\mathrm{m}\end{array}$ \\
\hline step & - Placing the barrel on the pallet \\
\hline step & - Packing the pallet into polyethylene (PE) foil \\
\hline step & -Measuring the Dr on PE foil surface \\
\hline step & - Taking swabs from the packaging file surface by a radiation safety officer \\
\hline step & - Barrel transportation by a driver sitting in the cab \\
\hline
\end{tabular}

Fig. 5. Sequence of procedures during handling and transportation according to alternative 1 .

Time schedule for steps 1 to 5 refers to 4 pieces of transported barrels. DR and time data obtained from the detailed description of the steps necessary for handling of the fixation product of used sorbents of alternative no. 1 are specified in Table 6.

Compared to alternative no. 0, temporary storage in room B was omitted, enabling to skip four steps of the procedure; a new step - wrapping pallets into polyethylene foil to reduce surface contamination - has been added. DR values on the surface of the packaging file (pallet with four pieces of barrels wrapped in PE foil) were $20 \mathrm{mSv} / \mathrm{h}$. It means that the limit of 10 $\mathrm{mSv} / \mathrm{h}$ - set for exclusive transport in the nuclear power plant site - has been exceeded. DR limit on the surface of the transported packaging file on the edge of the vehicle is $1.43 \mathrm{mSv} / \mathrm{h}$. This limit for exclusive transport would then be met. If we consider a given promising alternative solution, the subject is assessed Nuclear safety agency. Significant reduction in dose absorbed by workers participating in the process can be considered as a positive result of alternative no. 1 if the same result has been achieved. 
Table 6. Calculation of radiation load during handling and transportation, alternative 1 [5].

\begin{tabular}{|c|c|c|c|c|c|c|}
\hline Step & $\begin{array}{c}\text { Number } \\
\text { of } \\
\text { employees }\end{array}$ & $\begin{array}{c}\text { Distance } \\
\text { from the } \\
\text { source }\end{array}$ & $\begin{array}{c}\text { Time } \\
{[\mathbf{m i n}]}\end{array}$ & $\begin{array}{c}\text { DR } \\
{[\mathbf{m G y} / \mathbf{h}]}\end{array}$ & $\begin{array}{c}\text { Dose } \\
{[\mathbf{m S v}]}\end{array}$ & $\begin{array}{c}\text { Overall dose } \\
{[\mathbf{m S v} / \mathbf{h}]}\end{array}$ \\
\hline 1. & 2 & $0.5-1.5$ & 8 & 0.502 & 0.066 & 0.122 \\
\hline 2. & 2 & 1.0 & 6 & 1.433 & 0.143 & 0.286 \\
\hline 3. & 2 & 1.0 & 1 & 1.433 & 0.023 & 0.046 \\
\hline 4. & 1 & 2.0 & 4 & 0.232 & 0.015 & 0.015 \\
\hline 5. & 1 & 0.5 & 1 & 4.57 & 0.076 & 0.076 \\
\hline 6. & 1 & $2,0^{*}$ & 40 & 0.137 & 0.091 & 0.091 \\
\hline Sum total & $\mathbf{8}$ & & $\mathbf{6 0}$ & & $\mathbf{0 . 4 1 4}$ & $\mathbf{0 . 6 3 6}$ \\
\hline
\end{tabular}

*shielding by the $c a b$

\subsection{Alternative 2}

The procedure remains the same as with alternative no.1. Having different gear for the transport vehicle, overall reduction of DR can be achieved. Before transportation, workers place a pallet with four pieces of shielded barrels onto the vehicle. Barrels are opened then and concrete lids are placed on the loading area of the vehicle near the pallet. The pallet with four shielded barrels has been prepared on the loading area at $1 \mathrm{~m}$ distance from the end of the loading area and $1.6 \mathrm{~m}$ from the driver's cab. Two employees fix the transported barrel by a vacuum holder and lower it into the pre-prepared shielded barrel. The barrel is placed then into the opening in the shielded concrete barrel and the vacuum holder is released. To load the whole consignment, the procedure is repeated four times. When the 601 barrels are placed into the shielded containers, workers close the shielded containers by concrete lids and secure the 2001 MEVA containers by lids and hoops. Workers leave then the loading area and stay at a distance fixed by a radiation safety technician. Radiation safety technician measures the DR on the surface of the transported shielded container by taking swabs to check the surface contamination (SC), assesses the values of DR and SC taking into consideration transportation conditions and limits in NPP site and issues the documents necessary for transport.

Time schedule of each step of alternative no. 2 are in figure 6 and the DR data and time data obtained from the detailed procedure description necessary for handling of the fixation product of used sorbents are specified in Table 7.

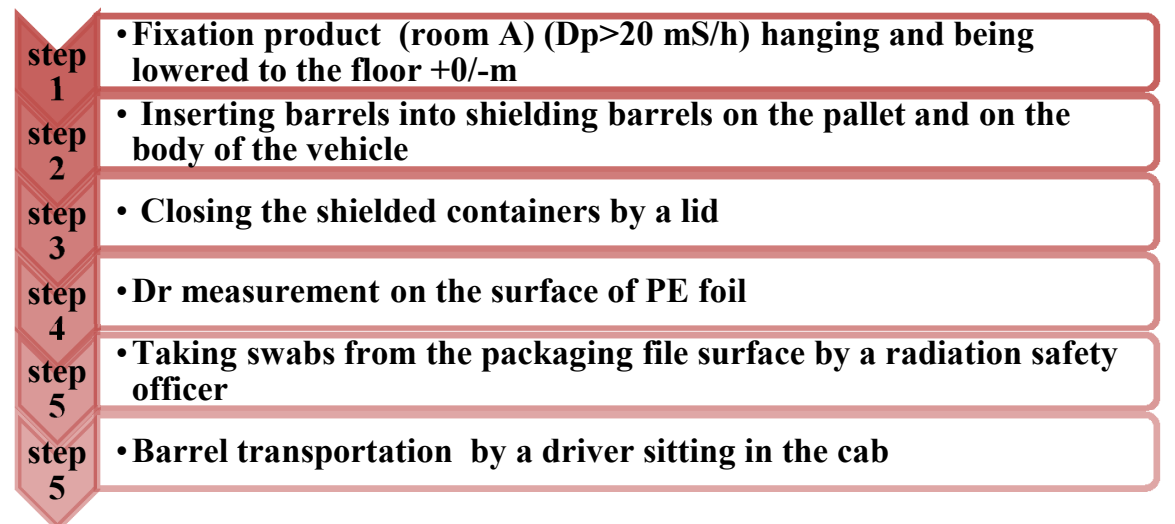

Fig. 5. Sequence of steps during handling and transportation under alternative 2. 
Table 7. Calculation of radiation load during handling and transportation, alternative 2 [5].

\begin{tabular}{|c|c|c|c|c|c|c|}
\hline Step & $\begin{array}{c}\text { Number } \\
\text { of } \\
\text { employees }\end{array}$ & $\begin{array}{c}\text { Distance } \\
\text { from the } \\
\text { source }\end{array}$ & $\begin{array}{c}\text { Time } \\
{[\mathbf{m i n}]}\end{array}$ & $\begin{array}{c}\text { DR } \\
{[\mathbf{m G y} / \mathbf{h}]}\end{array}$ & $\begin{array}{c}\text { Dose } \\
{[\mathbf{m S v}]}\end{array}$ & $\begin{array}{c}\text { Overall } \\
\mathbf{d o s e} \\
{[\mathbf{m S v} / \mathbf{h}]}\end{array}$ \\
\hline 1. & 2 & $0.5-1.5$ & 8 & 0.502 & 0.066 & 0.122 \\
\hline 2. & 2 & 1.0 & 6 & 1.433 & 0.143 & 0.286 \\
\hline 3. & 2 & 1.0 & 4 & 0.358 & 0.023 & 0.046 \\
\hline 4. & 1 & 2.0 & 4 & 0.058 & 0.004 & 0.004 \\
\hline 5. & 1 & 0.5 & 2 & 1.44 & 0.038 & 0.038 \\
\hline 6. & 1 & $2.0^{*}$ & 45 & 0.058 & 0.043 & 0.043 \\
\hline $\begin{array}{c}\text { Sum } \\
\text { total }\end{array}$ & & & 67 & & $\mathbf{0 . 3 1 7}$ & $\mathbf{0 . 5 3 9}$ \\
\hline
\end{tabular}

*shielding by the cab

By using shielded containers for transport, the DR on the packaging file surface decreased from $20 \mathrm{mSv} / \mathrm{h}$ to $5 \mathrm{mSv} / \mathrm{h}$, compared to the alternative No. 1 . This means that the limit for land transport in nuclear power plant site has been met. By means of DR reduction coefficient, DR value on the edge of the vehicle will be $0.454 \mathrm{mSv} / \mathrm{h}$ provided that the packaging file is placed at the distance of approx. $0.8 \mathrm{~m}$ from the edge. None of the measured and calculated values exceed the limit for exclusive transport. The conclusions presented above show that the procedure in alternative no. 2 is applicable into practice without changing the legislation or having exceptions to the specified limits. Significant reduction in doses absorbed by workers participating in the operation with the same result - to transport the final product from the point $\mathrm{A}$ to point $\mathrm{B}$ - can be considered as a positive result of alternative no.2. However, alternative no. 2 compared to alternative no.1 requires more equipment (shielded containers) what means higher expenses.

\section{Discussion}

All of the above mentioned procedures of handling of the final fixation product of used sorbents can be compared considering several aspects:

- observing the limits of radiation safety,

- time needed for the process,

- economic aspect,

- technological demands.

Alternative no. 0 is more time consuming, since it includes the initial re-stocking of the final product of the room A into room B and from the room $\mathrm{C}$. This means the highest dose rate for workers.

Alternative no. 1 and no. 2 omit the process of stock transfer in order to reduce radiation load for workers participating in the process. Stock transfer and temporary storage of final product is worked into the valid work program and justified by running test for compactness of the final product which are performed on every 10th barrel containing the final product. This operation is not described in the individual steps as it is not linked directly with transport and, moreover, radiation dose for workers carrying out measurement would be the same. Alternative no. 1 and 2 only describe operations required for transport of the final product. Since strength tests of each tenth barrel are one of the conditions of product storage, it means that, with the overall production of 100 pieces of 601 barrels, the proposed procedure in alternative no. 1 and 2 is applicable for $90 \%$ of the barrels from the overall production. $10 \%$ of the barrels would be handled following the valid work program. 
Table 8 shows absorbed doses for workers who have taken part in transport and handling of final fixation product. The table below shows time data of individual steps of the procedure.

Table 8. Comparison of time schedule and radiation rate for each procedure

\begin{tabular}{|c|c|c|c|c|}
\hline $\begin{array}{c}\text { Work } \\
\text { procedure }\end{array}$ & $\begin{array}{c}\text { Number of } \\
\text { employees }\end{array}$ & Time [min] & $\begin{array}{c}\text { Absorbed dose / } \\
\text { worker } \\
{[\mathbf{m S v}]}\end{array}$ & $\begin{array}{c}\text { Overall } \\
\text { absorbed dose } \\
{[\mathbf{m S v} / \mathbf{h}]}\end{array}$ \\
\hline $\begin{array}{c}\text { According to } \\
\text { the program }\end{array}$ & 17 & 93 & 0.075 & 1.278 \\
\hline Alternative 1 & 8 & $\mathbf{6 0}$ & 0.079 & 0.636 \\
\hline Alternative 2 & 8 & 65 & $\mathbf{0 . 0 6 7}$ & $\mathbf{0 . 5 3 9}$ \\
\hline
\end{tabular}

From the point of view of radiation load, alternative no. 2 is the most appropriate from the above mentioned solutions. With the overall production of 100 pieces of 601 barrels, the whole procedure needs to be repeated 25 times, resulting in overall dose reduction for all workers present from $31.95 \mathrm{mSv}$ to $13,475 \mathrm{mSv}$. Difference between estimated absorbed dose according to the valid work procedure program and suggested alternative no. 2 is 16,628 $\mathrm{mSv}$. At the same time, it will reduce the time required for transport of packaging file by almost one third.

\section{Conclusion}

Radiation safety is an important component and limiting condition for all the works in nuclear power plant site. On the basis of work procedures and technological methods of radioactive waste processing, it was possible to accurately measure and monitor doses absorbed by all workers. By evaluating the measured values of dose rates and time needed for each step - handling and transport - it may be possible to make an analysis of absorbed doses during each steps of the work procedure and to propose an alternative which would reduce time during packaging file transport in NPP site but, in particular, it would lead to reduction in absorbed doses for the employees involved.

Acknowledgments: This article was supported by the Grant Agency Ministry of Education SR KEGA - project no. 014UKF-4/2016.

\section{References}

1. IAEA: The Principles of Radioactive Waste Management, Safety Series No. 111-F, IAEA, Vienna (1995).

2. M. ZACHAR, V. NEČAS, Problematika nakladania s rádioaktívnymi odpadmi v Slovenskej republike. Jaderná energetika v pracích mladé generace. ČNS. Brno, Česká republika..ISBN 978-80-02-02116-2, p. 49-55,(2008)

3. IAEA, Predisposal Management of Low and Intermediate Level Radioactive Waste: Safety Guide No. WS-G-2.5. Vienna: IAEA (2003)

4. IAEA, Regulations for the Safe Transport of Radioactive Material: Safety Requirements No.TS-R-1. Vienna: IAEA, (2005)

5. Hlubík, M. Radiačná bezpečnost' pri transportoch rádioaktívnych odpadov v areáli JE [Diploma thesis]. MTF STU, (2013)

6. VYHLÁŠKA ÚJD SR č.57/2006 Z.z., ktorou sa ustanovujú podrobnosti o požiadavkách pri preprave rádioaktívnych materiálov (2006) 
7. Vyhláška ÚJD SR č. 30/2012 Z.z., ktorou sa ustanovujú podrobnosti o požiadavkách pri nakladaní s jadrovými materiálmi, rádioaktívnymi odpadmi a vyhoretým jadrovým palivom (2012)

8. Dulanska, S., Meloun, M., Matel, L. Scaling model for prediction of radionuclide activity in cooling water using a regression triplet technique. Journal of radioanalytical and nuclear chemistry 285.3. pp.547-553. (2010)

9. Engineering and Operating Guide for DOWTHERM SR-1 and DOWTHERM 4000: Inhibited Ethylene Glycol-based Heat Transfer Fluids, www.dowtherm.com (2008)

10. IAEA, Radioactive Waste Management - Status and trends. Issues No. 4., Vienna, (2005)

11. Seidl, M., Tomek. M. Transportation of radioactive materials. Slovenské jadrové fórum. Ročník 6., No I, (2011)

12. SÚJB, Přeprava radioaktivních látek. Bezpečnostní návod BN-JB-1.13. https://www.sujb.cz, (2011)

13. IAEA, Regulations for the Safe Transport of Radioactive Material,Viena, (2009)

14. Tureková, I., Rybakowski, M., Szabová, Z., Dudarsku, G. Efficiency rating of vision in terms of prevention of road accidents at work. Advanced Materials Research, vol. 734737, 2013, pp. 1613-1616 (2013)

15. Shcherba, I.D., Bekenov, L.V., Antonov, V.N., Noga, H., Uskokovic, D., Zhak, O., Kovalska, M.V., Electronic structure and X-ray spectroscopic properties of $\mathrm{YbNi2}$ 2, Journal of Electron Spectroscopy and Related Phenomena, Volume 212, pp. 5-10. (2016)

16. Strážovec, R. et al. Aktualizácia limít a podmienok pre prevádzku technológii. JZ TSÚ RAO. SNUS, Častá - Papiernička, (2014)

17. Hornáček, M., Nečas, V., Bezák, P. Calculation of the dose load during dismantling of large components in the process of decommissioning of nuclear installations. ICEM2013, September 8-12, Brussels, (2013) 